ROCZNIKI PEDAGOGICZNE

Tom 11(47), numer specjalny - 2019

DOI: http://dx.doi.org/10.18290/rped.2019.11s-1

\title{
OD KOMITETU REDAKCYJNEGO
}

Numer specjalny Roczników Pedagogicznych w roku 2019 zawiera materiały Ogólnokrajowej Konferencji Naukowej nt. „Wyzwania współczesnej pedagogiki resocjalizacyjnej - od teorii do praktyki”, zorganizowanej 11 kwietnia 2018 roku w Katolickim Uniwersytecie Lubelskim Jana Pawła II z okazji jubileuszu stulecia powstania Uniwersytetu (w tym również kierunku Pedagogika) oraz powołania w Polsce Służby Więziennej (dekretem Marszałka Józefa Piłsudskiego z 7 lutego 1919 roku).

Konferencja była pokłosiem projektu naukowo-badawczego pt. Wychowawczy wpływ resocjalizacji na osoby pozbawione wolności $-w$ teorii i praktyce, realizowanego w Katolickim Uniwersytecie Lubelskim Jana Pawła II pod kierownictwem ks. dr. hab. Kazimierza Pierzchały, prof. KUL.

Publikacja zawiera 32 artykuły, których autorami są przedstawiciele dziesięciu ośrodków naukowych w Polsce oraz polscy praktycy penitencjarni. Najwięcej miejsca poświęcono zagadnieniu resocjalizacji skazanych, w tym m.in. przez pracę, a ponadto prezentowane są artykuły poruszające problematykę: dysfunkcjonalności w rodzinie, niedostosowania społecznego, izolacji penitencjarnej, przestępczości narkotykowej, kary śmierci, przywództwa, kształcenia zawodowego, zachowania suicydalnego, probacji skazanych, duszpasterstwa więziennego oraz elementy tematyki ukazującej uwarunkowania życia.

Resocjalizacja skazanych. Życie człowieka charakteryzują wartości realizowane w warunkach wolności. Dotyczy to także resocjalizacji. Wartościami zajmuje się aksjologia, a w pedagogice - aksjologia wychowania. Jeden z artykułów podejmuje problem roli wartości w kontekście oddziaływań resocjalizacyjnych, kolejny odnosi się do kwestii wolontariatu w procesie resocjalizacji w zakładach karnych oraz do możliwości wykorzystania wolontariatu jako narzędzia zmiany postaw skazanych.

Należy pamiętać, że nie ma uniwersalnych i bezwzględnie skutecznych metod resocjalizacji, zarówno w odniesieniu do dorosłych sprawców przestępstw, przebywających w zakładach karnych, jak i w stosunku do młodych osób sprawiających problemy wychowawcze. Ważne jest to, aby wszelkie 
oddziaływania wychowawcze wiązały się z ,ukształtowaniem prawidłowej postawy wychowanka wobec przyszłego życia", a więc z przygotowaniem się do lepszego życia poprzez naukę, zdobycie zawodu, znalezienie własnego miejsca w społeczeństwie i założenie własnej zdrowej i trwałej rodziny.

Proces resocjalizacji opiera się na dwóch podstawowych metodach oddziaływania na jednostkę. Pierwszą z nich jest oddziaływanie oparte na bezpośredniej relacji wychowawcy z wychowankiem, drugą zaś metodą jest praca oparta na grupie społecznej. Przedmiotem analizy jest dynamika powstania grupy i pogłębiony proces jej tworzenia. W procesie resocjalizacji grupa należy do podstawowych instrumentów oddziaływań socjoterapeutycznych. Umiejętne sterowanie powstaniem grupy i dynamiką zmian w niej zachodzących gwarantuje sukces $\mathrm{w}$ oddziaływaniach resocjalizacyjnych w przypadku nieletnich.

$\mathrm{Z}$ tą tematyką wiąże się zagadnienie neuroedukacji, która wykorzystuje techniki treningu na poziomie neuronalnym w celu skutecznej stymulacji mózgu w procesie uczenia się zarówno dzieci, jak i dorosłych, osób zdrowych i z niepełnosprawnościami.

W kolejnym artykule została podjęta próba udowodnienia tezy o konieczności projektowania w procesie resocjalizacji konkretnych rozwiązań, które uwzględniają zarówno działania skierowane bezpośrednio do samego skazanego, jak również postępowanie obejmujące systemowe rozwiązania i udział społeczeństwa w tym procesie.

Programy profilaktyczne, readaptacyjne, reintegracyjne lub doskonalące funkcjonowanie systemu społecznego dla określonej grupy czy środowiska społecznego powinny wychodzić od najniższego poziomu, czyli konkretnych osób uwikłanych w problemy społeczne i społeczeństwa, aby zmienić ich sposób myślenia i wartościowania, wzajemnego funkcjonowania i uczestnictwa w danym systemie. Działania reintegracyjne, w tym również samopomocowe, mają na celu odbudowanie i podtrzymywanie umiejętności uczestniczenia w życiu społeczności lokalnej i przyjęciu nowych akceptowanych ról społecznych w miejscu pracy, zamieszkania lub pobytu na zasadzie wymiany dóbr materialnych i niematerialnych. Wymiana społeczna oparta na odpowiedzialności za drugiego człowieka, na zaufaniu oraz na prawie do wyboru i zaciągania zobowiązań stanowi szansę dla wykluczonych społecznie w odnajdywaniu własnych zasobów i potencjałów w warunkach środowiska otwartego.

W następnym artykule są zaprezentowane stanowiska wychowawców Służby Więziennej odnośnie do znaczenia relacji ze skazanymi dla optymalizacji prowadzonych działań naprawczych. Oceniona została rola funkcjonariuszy Służby Więziennej w procesie resocjalizacji osadzonych na przykładzie oddziaływań prowadzonych w trzech jednostkach penitencjarnych. 
Praca skazanego. W ujęciu polskiego prawa karnego i wykonawczego do resocjalizacji osób odbywających sankcje izolacyjne zalicza się: pracę, nauczanie, zajęcia kulturalno-oświatowe i sportowe, podtrzymywanie kontaktów z rodziną i światem zewnętrznym, nagrody i kary dyscyplinarne oraz nowe środki i metody oddziaływania na skazanych. Artykuł odnoszący się do tych zagadnień został oparty na własnych badaniach i ustaleniach korelacji zmiennych, jakie towarzyszą skazanym w czasie podejmowanej pracy, w kontekście resocjalizacji penitencjarnej.

Dysfunkcjonalność. Poważnym problemem współczesnej rodziny jest jej dysfunkcyjność. Składają się na nią zaburzenia procesów naruszające strukturę więzi rodzinnych, a wskutek tego trudności w wypełnianiu prawidłowych funkcji. Artykuł na ten temat ukazuje wybrane następstwa dorastania w dysfunkcyjnym środowisku rodzinnym.

$\mathrm{Z}$ dysfunkcjonalnością rodziny ściśle jest powiązane zagadnienie przemocy w rodzinie. Ciągle można się spotkać z pewnymi stereotypami dotyczącymi tego zjawiska, co często doprowadza do ukrywania przez rodzinę problemu przemocy.

Niedostosowanie społeczne. W niniejszej publikacji przedstawiono m.in. zjawisko niedostosowania społecznego osób nieletnich. Poruszona została problematyka przyczyn niedostosowania społecznego wynikających z uwarunkowań środowiska rodzinnego, szkolnego i społecznego, objawy niedostosowania społecznego wraz z etapami wykolejenia, jak również realne skutki powstałego zjawiska.

Izolacja. Minimalizowanie izolacji wewnętrznej w celu zracjonalizowania karania w stronę cywilizacyjno-kulturowych rozwiązań powinno się odbywać nie przez mechaniczne i symplicystyczne narzucanie wzorów, ale poprzez rzeczowe powiększanie zakresu samokontroli zachowania się skazanych wobec innych osób oraz zachowania się w grupach.

Kolejny artykuł przedstawia analizę ewolucji doktryny systemu penitencjarnego w kontekście przemian ustrojowych, jakie zaszły w Polsce na początku lat dziewięćdziesiątych. Autor zwraca uwagę, że wprowadzane zmiany powinny uwzględniać dwutorowy charakter systemu penitencjarnego, który obejmuje dwie grupy podmiotów: osadzonych oraz osoby nadzorujące.

Przestępczość narkotykowa. Poważnym zagrożeniem płynącym ze współczesnego środowiska jest narkomania. Dotyka ona coraz więcej osób, w szczególności młodych. Wiąże się z tym coraz bardziej powszechne w środowisku lokalnym zjawisko przestępczości narkotykowej. Zasięg tego zjawiska, jego różnorodność i następstwa powodują, że należy traktować je bardzo poważnie. 
Kara śmierci. Życie ludzkie jest najwyższą wartością w hierarchii dóbr chronionych prawem zarówno z punktu widzenia pojedynczego człowieka, jak i z perspektywy całego społeczeństwa. Dyskusja tocząca się na temat kary śmierci jest oparta głównie na dwóch konkurujących ze sobą stanowiskach. Pierwsze z nich - retencjonizm - wyraża przekonanie co do słuszności wykonywania kary śmierci oraz odnośnie do godzenia się z pewnymi ograniczeniami jej stosowania. Drugie zaś to abolicjonizm, który sprzeciwia się zachowaniu kary śmierci w ustawodawstwie karnym. Dla ochrony życia nie powinien mieć znaczenia obowiązujący system prawny, religijny, wyznawany światopogląd czy możliwe różnice kulturowe, bowiem prawo do życia przysługuje każdej istocie ludzkiej.

Przywództwo. Zagadnienie przywództwa nurtuje wielu współczesnych badaczy reprezentujących różne dyscypliny naukowe, w tym również tych, którzy są zainteresowani problemem bezpieczeństwa. Sposoby kierowania innymi zostały opisane w literaturze i są wyraźnie zdefiniowane, a wszystkie łączy wspólna cecha: oscylują one między dwoma biegunami, czyli autokratyzmem a demokratyzmem.

Kształcenie zawodowe, nauka. W artykule ujęto funkcjonowanie jednostki w warunkach instytucji totalnej na przykładzie więzienia, ze szczególnym uwzględnieniem udziału osoby skazanej w procesie uczenia się i samokształcenia. Celem artykułu było przedstawienie problematyki nauczania osadzonych w jednostkach penitencjarnych jako czynnika resocjalizacji, a także ukazanie potencjału i możliwości Służby Więziennej w kształceniu osób pozbawionych wolności. Problem kształcenia zawodowego osób osadzonych w Polsce dotyczy szeregu uwarunkowań i wiąże się z wieloma trudnościami. Wsparcie w pozytywnej readaptacji zawodowej osób osadzonych jest ważnym zagadnieniem, które skłania do szerokiej dyskusji społecznej na ten temat. Wszystkie organizacje, które świadczą pomoc w kwestii osób wykluczonych społecznie (także tych zagrożonych wykluczeniem), czyli również osób skazanych, wykonują wiele zadań, które mają na celu wsparcie tych osób w odniesieniu sukcesu w obszarze zawodowym.

Samobójstwa, zachowania suicydalne. Artykuł dotyczy uwarunkowań zachowań suicydalnych u adolescentów. Na podstawie wybranych badań dokonano weryfikacji czynników tzw. ryzyka, które w znacznym stopniu oddziałują na młodzież. Poszukiwania uwarunkowań zachowań suicydalnych prowadzone były wokół czynników ryzyka związanych z rodziną i jej sytuacją/problemami, tkwiących w jednostce oraz związanych ze środowiskiem społecznym.

Probacja. Zmieniający się obraz polityki karnej Państwa i wiodąca w niej rola kar alternatywnych wobec kary pozbawienia wolności to kolejny dział 
niniejszej publikacji. Należy pamiętać, że ciągle rosną oczekiwania w zakresie podniesienia skuteczności działań mających na celu pomoc skazanemu opuszczającemu jednostkę penitencjarną w społecznej readaptacji. Dostrzegając te zjawiska, autor prezentuje systemowe podejście do readaptacji społecznej skazanych, opierając się na nowym, hybrydalnym modelu przygotowania skazanego do życia na wolności.

Duszpasterstwo więzienne. Biblijne źródła jako podstawa do pracy z człowiekiem izolowanym w więzieniu wskazują na potrzebę właściwej pracy penitencjarnej. Artykuł ukazuje funkcjonowanie duszpasterstwa więziennego w ostatnich stu latach, w kontekście okresu po 1990 roku i jego obecnego rozwoju, poprzez różne formy naprawiania i budowania relacji interpersonalnych. Zagadnienie to zostało poszerzone o świadectwa więźniów, którzy zawdzięczają duszpasterstwu więziennemu przemianę ich życia.

Uwarunkowania życia. Ostatni artykuł ukazuje bezpieczną przestrzeń życia człowieka na pograniczu polsko-rosyjskim. Autor opracowania na podstawie badań zwraca uwagę na uwarunkowania, jakie rządzą życiem mieszkańców na pograniczu polsko-rosyjskim. Wśród wielu podziałów barier dokonywanych z punktu widzenia ich funkcji na szczególną uwagę zasługują te, które uwzględniają aspekt rozwoju społeczno-gospodarczego.

Wszystkie artykuły zamieszczone w niniejszym numerze Roczników Pedagogicznych ściśle wpisują się w próbę podsumowania praktyki pedagogicznej $\mathrm{i}$ jej zestawienia $\mathrm{z}$ wymaganiami teoretycznymi i praktycznymi.

W dniu 11 kwietnia 2018 roku była okazja spotkania się akademików reprezentujących myślenie racjonalno-idealistyczne z bezpośrednimi wykonawcami zadań związanych z szeroko pojmowanym zagadnieniem resocjalizacji penitencjarnej. Na forum wymiany, merytorycznego sporu z zakresu scjentyzmu poznawczego można formułować odważne, mocne i abolicjonistyczne twierdzenia oraz hipotezy dotyczące aksjonormatywnego porządku dla modelu wykonania kary pozbawienia wolności. Zauważyć należy, iż miejscem dysputy naukowej był Katolicki Uniwersytet Lubelski Jana Pawła II. Tym samym wyraźnie wybrzmiewa potrzeba włączenia w nurt wnioskowania sceptyzmu krytycznego, wartościowania symbolicznego i duchowego, o cechach esencjonalizmu holistycznego, na temat humanizacji procesu karania.

Autorzy niniejszej publikacji w formie relacyjno-problemowej dokonują wieloanalitycznego ustrukturalizowania głównych zagadnień, które mają wpływ na rozwój oraz deformację i znaczące uproszczenia systemu sprawiedliwości karzącej. Zaprezentowane analizy na poziomie matrycy rozważań, w sferze 
resocjalizacji skazanych zostały podporządkowane regułom myślenia, właściwym sceptyzmowi krytycznemu oraz scjentyzmowi hermeneutycznemu.

Czytelny i artykułowany światopogląd naukowy odnosił się do realiów wnioskowania i wartościowania, które można określić jako rozumowanie materialno-duchowe, racjonalne, realne, empirystyczne i systemiczne. Jedynie bowiem, jak wykazali autorzy referatów, w szablonie transkulturowym, uwzględniającym powyższe predykatory postępowania, badacze dokonują prawomocnych i probabilistyczno-aproksymacyjnych rozstrzygnięć.

Odmienne stanowienie od powyższego wzorca, porządku normatywnego, organizacyjnego i wykonawczego w segmencie resocjalizacyjnym prowadzi prostą drogą do rozwiązań symplistycznych i symplicystycznych. Przybierają one wówczas postać indykatoryjną, którą można porównać do rzeczywistości sofizmatycznej, rozstrzygnięć synkretycznych lub do materii z zakresu immanentyzmu epistemologicznego. Tym samym może być zakłamywany pierwotny sens ontologiczno-gnozeologiczny w całym systemie resocjalizacji instytucjonalnej wobec skazanych na karę pozbawienia wolności.

Zaprezentowany całościowy obraz rzeczywistości penitencjarnej odpowiada modelowi rozwiązań instytucjonalno-wykonawczych właściwych dla reformy systemu karania. Przegląd literatury, liczne badania własne, przywoływane krajowe oraz międzynarodowe opracowania empiryczne w całości potwierdzają, iż obecnie w kulturze dominuje trend ku zmianom jakościowym, wyrażającym się w postaci: misji wizji, celów strategicznych i operacyjnych, funkcji, zadań, metod i środków.

Przedstawiciele nauki zwrócili uwagę na spójność i holistyczność między przedzałożeniowymi propozycjami aksjologicznymi wykonywania kary pozbawienia wolności a sferą proaktywnego postępowania celowościowego w tym zakresie.

Na poziomie werbalizacji poznawczej należy rozbudować, opierając się na założeniach myślenia ontologicznego, treści przynależne dla paradygmatu teoretyczno-prakseologicznego. Innymi słowy, wykorzystując wiedzę kognitywistyczną, na bazie interdyscyplinarnych treści naukowych, w każdym sprawczym przedsięwzięciu reformistycznym próbuje się zbudować konstrukt sensorodny będący emanacją świata wartości.

Proponowane idee w sposób eklektyczny i addytywny powinny scalać dobro jednostki, wspólnoty i kultury. Działalność praktyczna to zaprojektowana metodyka i strategia uwzględniająca wszystkie fazy w celu osiągnięcia najwyższej skuteczności i efektywności. Należy również przypomnieć, iż oglądu rzeczywistości więziennej i readaptacyjnej powinno się dokonywać z udziałem aksjomatów: kontekstu, synergii, równowagi i zasadności. 
Interesujące, wielopłaszczyznowe i wielowątkowe akademickie dywagacje przedłożone w niniejszej publikacji pokonferencyjnej wskazują, iż kształtowanie zintegrowanych propozycji legislacyjno-wykonawczych jest ujmowane w modelu karania i systemu pomocy postpenitencjarnej w sposób personalistyczny. Nieustannie więc należy podążać w kierunku artykułowania oraz dalszych zmian pod kątem zastosowania substancjonalnych antecedensów, określających interweniowanie w kategoriach: trwałości, trafności, skuteczności, efektywności, innowacyjności, kosztochłonności i funkcjonalności. Rezygnowanie z powyższej staranności sprowadziłoby rzeczywistość penitencjarną do zagregowanej i mechanistycznej świadomości, która staje się powodem do wysuwania tez reformacyjnych, odpowiadających normatywności kontrkulturowej, w miejsce interakcjonizmu transracjonalnego.

Właściwą płaszczyzną odniesienia, jako nadrzędną i symboliczną, wartościowo-twórczą, jest sfera tożsamościowa. To ona ma największy wpływ na życie jednostki oraz kreowanie instytucjonalno-organizacyjnego porządku systemów wspólnotowych. Pomijanie dowolnego segmentu z globalnego konstruktu metodologicznego, w obszarze metaanalizy tożsamości kulturowej, prowadzi bezpośrednio do sformatyzowania obrazu badanej rzeczywistości. Bardzo niekorzystnym zabiegiem jest zastępowanie wówczas kategorii aksjologicznych ich paliatywami, podporządkowanymi paradygmatyczności technokratycznej w miejsce humanistycznej. Chęć zrywania $\mathrm{z}$ aksjonormatywnym porządkiem na rzecz rozwiązań utylitarnych i neoliberalnych może wprowadzać w obszar praktycznych działań pedagogicznych chaos, polegający na formalizmie instytucjonalnym i procedurach odbiegających od transgresywnego wzorca poprawy osobowej.

Wystąpienia przedstawicieli środowiska praktyków więziennictwa w dużej części koncentrowały się na zagadnieniach związanych z kompetencyjnością i umiejętnościami stawiania pełnej, rozbudowanej diagnozy psychopedagogicznej dla skazanych odbywających karę pozbawienia wolności. Należy ją formułować po uprzedniej anamnezie, gdyż stanowi ona oś budowania programów resocjalizacyjnych, z uwzględnieniem fazy katamnestycznej i prognostycznej. Te wszystkie etapy postępowania stanowią żelazną konstrukcję, pozwalającą na zaadaptowanie pozytywnych wzorców idei oraz zasad wychowania resocjalizacyjnego w stadium karania i stadium postpenitencjalnym.

Gwarancją tego stanu rzeczy są trzy reguły hermetycznego poznania, które kategoryzują indykatoryjność sprawczą. Zrozumieć można bowiem część, szczegół tylko poprzez całość, zaś całość po zrozumieniu części. Poznawanie człowieka może odbywać się poprzez oddawanie mu świata ludzi, na drodze zawierzenia, współtworzenia i jego rozumienia. Natomiast odsłaniając 
wspólnotowość, czynić to można jedynie poprzez mówienie i działanie na rzecz człowieka, gdyż wówczas definiujemy prawdę o kondycji społeczeństwa.

$\mathrm{Na}$ kanwie interesujących rozważań naukowych przedłożonych w niniejszym numerze Roczników Pedagogicznych należy zauważyć, iż pewien kryzys optymalnych i racjonalnych modeli oddziaływań pedagogiczno-korekcyjnych jest pochodną upowszechniania się w przestrzeni publicznej paradygmatu technokratycznego, gloryfikującego formalizm organizacyjny, w miejsce działań humanistycznych i personalistycznych. Tym samym może sprowadzać się to do rozrostu programów wykonawczych, odwołujących się do wzorców postantropologicznych, reifikacyjnych, segregacyjnych oraz redefiniujących dotychczasowe ustalenia metodologiczne w sferze nauki.

Na skutek tych przewartościowań czasem dochodzi do „urabiania” u skazanych na karę pozbawienia wolności niekorzystnych mechanizmów rozwojowych, komunikacyjnych i przystosowawczych, wpływających na ich podstawowe sprawności osobowe, sferę językowo-poznawczą, emocjonalno-motywacyjną i sensoryczną.

Działalność ta wymaga podejścia wielowymiarowego, z dochowaniem procedury o wieloczynnikowości predyktorów odpowiedzialnych za zadowalające rezultaty w kwestii skuteczności i efektywności stosowania sankcji izolacyjnych. Co najmniej należałoby ją poddać uprofilowaniu ze względu na cele, fazy i strategię oddziaływania. W pierwszym segmencie dynamika kontroli i zmiany powinna obejmować: jednostki, grupy i liczne środowiska zewnętrzne. Kolejny wymiar strukturalnej i proaktywnej interwencji to faza moderowania arsenałem zróżnicowanych metod i sposobów, uwzględniająca indukcję, rdzeń i zakończenie postępowania celowościowego. Ostatnie ogniwo planowanych przedsięwzięć stanowi strategia bazująca na relatywizmie ocennym, intencjonalności oraz bezpośrednich i pośrednich interwencjach.

Tak pozycjonowana działalność resocjalizacyjna gwarantuje pełną podmiotowość, autonomię, hubrystyczność wszystkim jego uczestnikom i pozwala na kreowanie sokratejskiego wzorca osobowego. Skazani na karę pozbawienia wolności stają się wówczas twórcami samych siebie, istotami zdolnymi do dezintegracji pozytywnej i przekuwania dotychczasowych negatywnych doświadczeń na rzecz korzystnych socjalizacyjnych wyborów.

Wszyscy uczestnicy naukowej debaty na temat: „Wyzwania współczesnej pedagogiki resocjalizacyjnej - od teorii do praktyki" uznali pierwszeństwo dla projekcji wykonawczych w ramach systemu penitencjarnego stosowania najnowszych propozycji myśli humanistycznej. Uwzględnia ona transgresyjność w sferze życia publicznego i duchowego człowieka, salutogenetyczne podejście do rozwiązywania sytuacji trudnych, określenie predyktorów ryzyka 
i odpowiadających im czynników ochronnych, zaakceptowanie formuły biofilizmu, preferowanie modelu dobrego i udanego życia oraz sięganie do twórczych zasobów i potencjałów integracyjnych jednostki.

Wiedza ta pozwala, na co zwrócili uwagę naukowcy z wielu ośrodków akademickich w Polsce, zbudować holistyczny system sprawiedliwości karzącej, w którym osoba wyzwala antecedensy rozwojowe w postaci samoświadomości, samowychowania, samopotwierdzenia oraz samorefleksyjności. Owe dynamizmy skutecznie doprowadzają do stanu dezintegracji pozytywnej, pozytywnego nieprzystosowania i wysokiej koherencji osób odbywających karę pozbawienia wolności, mierzonej jakością zasobów wiedzy, kompetencji społecznych, umiejętności integracyjnych, oraz swobody wyboru alternatywnych i aplastycznych sposobów zachowań.

Międzyśrodowiskowa konferencja, zorganizowana z okazji jubileuszu 100-lecia Katolickiego Uniwersytetu Lubelskiego Jana Pawła II oraz 100-lecia Służby Więziennej w Polsce, to szczególne wydarzenie naukowe, które udowodniło, iż rzeczywistość jest ważniejsza od idei oraz czas jest ważniejszy od miejsca. Horyzont kontroli i zmiany społecznej odnoszony do modelu sprawiedliwości karzącej pozwala także na stwierdzenie o wyższości jedności nad konfliktami oraz całości nad fragmentarycznością.

Z ogromną nadzieją należy oczekiwać kolejnych spotkań teoretyków akademickich z praktykami penitencjarnymi w celu dokonywania w świadomości powszechnej ewolucyjnych i radykalnych modernizacji na rzecz ugruntowywania solidaryzmu społecznego, będącego podstawą kulturotwórczych zmian w obrazie cywilizacji i ekologii życia człowieka oraz całego rodu ludzkiego.

Ks. dr hab. Kazimierz Pierzchała, prof. KUL Redaktor Naukowy numeru Ks. dr Marek Jeziorański (KUL) Dr Beata Mydtowska (WSP w Warszawie) 